\title{
Revitalisasi Humanisme dan Kritik Gadamer atas Metodologi
}

\author{
Hendrik Boli Tobi
}

hendrik.bolitobi@gmail.com

\begin{abstract}
Abstrak
Setelah memperkaya pengetahuan di bidang filologi, Gadamer pada akhirnya mengembangkan kajian hermeneutika yang berujung pada terbitnya buku Truth and Method. Ketika itu gagasan positivisme dan perkembangan ilmu baru, yaitu sosiologi, perlahan-lahan mendominasi khazanah ilmu-ilmu humaniora. Dominasi itu akhirnya direspons dan dilawan oleh sejumlah filsuf yang menganggap bahwa positivisme mengabaikan dimensi manusia yang begitu kompleks dan berbeda sama sekali dengan obyek penelitian ilmu-ilmu alam. Gadamer mengkritik keyakinan bahwa hanya melalui metodologi ilmu-ilmu alam, manusia dapat mencapai kebenaran. Gadamer menawarkan diskursus humanisme di tengah kepungan dominasi metodologi untuk mengembangkan humaniora. Gadamer mengangkat empat konsep penting dari tradisi humanisme, yaitu Bildung, sensus communis, pertimbangan, dan selera.
\end{abstract}

Kata Kunci: metodologi, humanisme, humaniora, positivisme, Altertumswissenschaft, Methodenstreit, Verstehen, Erklären, Naturwissenschaften, Geisteswissenschaften, Bildung, sensus communis, pertimbangan, selera.

Hendrik Boli Tobi adalah Mahasiswa Pascasarjana STF Driyarkara.

\section{Pendahuluan}

Ada dua topik utama yang dibahas dalam tulisan ini, yaitu pertama, kritik Gadamer atas dominasi metodologi sebagai jalan utama mencapai kebenaran. Kedua, upaya Gadamer 
merevitalisasi humanisme yang dipinggirkan dari panggung filsafat dan ilmu pengetahuan. Sebelum masuk ke dalam pembahasan dua topik tersebut, kita perlu lebih dulu mengetahui perkembangan pemikiran Gadamer. Gadamer adalah seorang filsuf yang berumur panjang (lebih dari 100 tahun) dan menjalani kehidupan yang ditandai dengan semangat zaman atas kemajuan teknologi tetapi sekaligus dibayangi oleh peristiwa-peristiwa kelam yang menyebabkan jutaan orang menjadi korban akibat Perang Dunia I dan II.

Berbagai peristiwa tersebut telah membawa Gadamer untuk memikirkan filsafat yang bisa membawa manusia ke arah yang lebih baik. Dari perjalanan hidupnya terlihat Gadamer mengalami berbagai perubahan pemikiran yang dimulai dari ketertarikan pada pemikiran Immanuel Kant sampai menjadi seorang ahli hermeneutik yang diakui oleh banyak kalangan intelektual.

\section{Perjalanan Hidup}

Hans-Georg Gadamer lahir di Marburg, Jerman, pada 11 Februari 1900. Ayah Gadamer bernama Johannes Gadamer, seorang profesor kimia yang terobsesi dengan keunggulan ilmu pengetahuan alam yang telah membawa berbagai kemajuan teknologi. Johannes Gadamer menginginkan anaknya untuk belajar ilmu-ilmu alam sejak dini supaya bisa menjadi seorang ahli ilmu alam seperti dirinya. Johannes Gadamer mengirim Gadamer untuk belajar di Heilig-Geist-Gymnasium, suatu sekolah yang memprioritaskan ilmuilmu alam dan membatasi pengajaran ilmu-ilmu sosial dan humaniora, ${ }^{1}$ dengan harapan Gadamer bisa mengembangkan pengetahuannya dan kelak menjadi ahli di bidang ilmuilmu alam. Di sekolah itu Gadamer menempa kebiasaan untuk berpikir secara ilmiah mengikuti metode-metode yang ketat dari ilmu-ilmu alam.

Namun, ternyata perjalanan intelektual Gadamer mengalami titik balik yang membawanya untuk mendalami dan mencintai bidang pengetahuan kemanusiaan. Saat

\footnotetext{
${ }^{1}$ Martinho G. da Silva Gusmao, Hans-Georg Gadamer: Penggagas Filsafat Hermeneutik Modern yang Mengagungkan Tradisi, Yogyakarta: Kanisius, 2013, hlm. 2-3.
} 
liburan sekolah, Gadamer yang sedang berada di perpustakaan milik ayahnya tertarik untuk membaca sebuah buku karya Immanuel Kant yang berjudul Kritik der reinen Vernunft. Setelah membaca buku itu, Gadamer seakan dibius oleh pemikiran Kant sehingga memutuskan untuk menekuni pengetahuan baru di luar ilmu-ilmu alam yang didapatkan dari ayah dan sekolahnya.

Ketika menginjak bangku kuliah, Gadamer mulai serius menekuni pengetahuan di luar ilmu-ilmu alam, seperti sastra, musik, psikologi, sejarah, seni, dan filsafat. Dari sinilah perjalanan intelektual sebagai seorang calon filsuf dimulai. Gadamer menjalani perjalanan intelektual dengan mempelajari pemikiran Kant dan Neo-Kantian. Setelah itu dia perlahan meninggalkan Neo-Kantian menjadi seorang fenomenolog di bawah asuhan Martin Heidegger.

Pengaruh Heidegger memang sangat besar, tetapi Gadamer akhirnya mengembangkan pemikirannya sendiri. Dalam upaya melepaskan diri dari pengaruh Heidegger, Gadamer tertarik belajar filologi dan secara tekun mengembangkan kemampuan berbahasa Yunani untuk memahami tulisan-tulisan dari masa Yunani klasik, khususnya teks-teks dari Plato dan Aristoteles. Setelah memperkaya pengetahuannya di bidang filologi, Gadamer akhirnya mengembangkan kajian hermeneutikanya yang berujung pada terbitnya Truth and Method (TM). Gadamer menulis TM pada usia 60 tahun. Bisa disebut sangat terlambat bagi filsuf menulis karya besarnya di usia senja. Memang Gadamer menulis karya terbaiknya di usia senja, tetapi ternyata Gadamer terus produktif menulis berbagai esai dan artikel serta melakukan debat dengan sejumlah tokoh setelah TM diterbitkan.

Gadamer meninggal dunia pada 13 Maret 2002 dalam usia 102 tahun. Dilihat dari perjalanan hidupnya, Gadamer awalnya dibentuk oleh ayahnya untuk menggeluti ilmuilmu alam yang diyakini oleh ayahnya adalah ilmu yang terdepan di antara pengetahuanpengetahuan lain. Akan tetapi, momen perubahan terjadi ketika Gadamer muda membaca karya Kant. Dari karya Kant tersebut, Gadamer menyadari bahwa pengetahuan manusia tidak hanya berpusat pada ilmu pengetahuan alam. Momen tersebut bisa disebut 
sebagai salah faktor pendorong bagi Gadamer untuk mengkritik dominasi metodologi dari ilmu-ilmu alam yang ingin ditiru atau diadopsi sepenuhnya oleh bidang-bidang pengetahuan lain.

Gadamer juga menemukan bahwa penggunaan metodologi ternyata juga digunakan oleh kalangan filolog. Saat Gadamer mulai menekuni filologi, khususnya pendalaman mengenai teks-teks dari masa Yunani kuno (Altphilologie), dunia filologi saat itu didominasi oleh apa yang disebut dengan Altertumswissenschaft atau ilmu tentang masa Yunani klasik. Para filolog menggunakan pendekatan ilmu untuk memahami pemikiran Yunani. Werner Jaeger (seorang tokoh penting dalam filologi) adalah representasi dari tendensi Altertumswissenschaft. Dalam pembahasan mengenai Aristoteles, Jaeger ingin membangun suatu intepretasi yang asli.

Gadamer tidak ingin membaca teks-teks Yunani klasik dalam kerangka Altertumswissenschaft. Gadamer berpandangan bahwa penulis-penulis di zaman Yunani klasik mempunyai konteks tersendiri ketika menuliskan karya-karya mereka, dan konteks tersebut belum tentu sama dengan konteks kekinian pada saat sang penafsir hidup. Gadamer menyatakan bahwa jika kita hanya menerjemahkan dan mengulang kembali teks Yunani klasik, kita tidak akan menemukan diri kita di dalam teks tersebut. Itulah yang menjadi kelemahan dari aliran Jaeger dari filologi klasik. ${ }^{2}$

Studi atas filologi bisa disebut faktor kedua yang mendorong Gadamer untuk menuliskan pemikiran kritis atas metodologi yang juga merambah di bidang-bidang pengetahuan yang lain. Dari latar belakang kehidupan dan perkembangan pemikiran Gadamer tersebut, kita bisa melihat pengaruhnya pada perkembangan pemikiran Gadamer yang berpuncak pada TM di tahun 1960. Berikut ini adalah paparan atas kritik Gadamer terhadap klaim metodologi sebagai satu-satunya jalan mencapai kebenaran dan bagaimana Gadamer menghidupkan kembali tradisi pemikiran humanisme.

\footnotetext{
${ }^{2}$ Lihat Silverman, Hugh J (ed), Continental Philosophy IV: Gadamer and Hermeneutics, New York: Routledge,
} 1991, hlm. 16-17. 
III. Kritik Gadamer atas Dominasi Penggunaan Metodologi dalam Perkembangan Humaniora

\subsection{Pengaruh Positivisme dalam Perkembangan Ilmu-ilmu Sosial}

Pada tahun 1963 Descartes menghasilkan karya Discours de la Méthode atau dalam edisi bahasa Inggris The Discourse on Method. Tulisan Descartes tersebut merupakan tonggak terpenting bagi perkembangan ilmu pengetahuan dan filsafat modern (Descartes menjadi penanda mulainya filsafat modern). Sejak Descartes, metode kemudian menjadi pilihan utama dalam pengembangan pengetahuan manusia, khususnya banyak digunakan di bidang pengetahuan alam. Perkembangan pesat pengetahuan alam akhirnya menjadikan pengetahuan tentang alam menjadi suatu ilmu, yaitu suatu pengetahuan yang disusun berdasarkan hukum-hukum tertentu. Peranan metodelah yang mempercepat pengembangan pengetahuan manusia tentang alam.

Kemajuan yang telah dicapai oleh ilmu-ilmu alam mendorong sejumlah ilmuwan untuk mengaplikasikan metode ilmu alam untuk mengamati, menganalisis, dan memprediksi masyarakat. Bagi mereka, penelitian masyarakat tak jauh berbeda dengan penelitan tentang benda-benda. Pandangan semacam itulah yang mendasari lahirnya positivisme yang pengaruhnya masih berlangsung sampai saat ini.

Charles Montesquieu (1689-1755) adalah seorang filsuf yang menganjurkan kemungkinan mengembangkan ilmu tentang masyarakat yang menyerupai hukum utama Newton. Dalam The Spirit of the Laws (1748), sebagaimana disebutkan oleh Jonathan Turner, Montesquieu mengatakan bahwa masyarakat harus dipertimbangkan sebagai suatu "benda" dan dinamika masyarakat bisa ditemukan melalui observasi dan analisis yang sistematis. ${ }^{3}$

\footnotetext{
${ }^{3}$ Jonathan H. Turner, "The Origins of Positivism: The Contributions of Auguste Comte and Herbert Spencer" dalam George Ritzer and Barry Smart (eds), Handbook of Social Theory, London: Sage Publication, 2001, hlm. 30.
} 
Saint Simon (1760-1825) adalah orang yang pertama kali menggunakan istilah ilmu "positif" untuk ilmu tentang manusia dan masyarakat yang didasarkan pada observasi empiris. ${ }^{4}$ Dengan menggunakan analogi organisme, Simon melihat masyarakat sebagai suatu jenis organisme yang hukum perkembangan dan organisasinya bisa ditemukan dan patologi masyarakat dapat diperlakukan seperti organisme biologis. Simon, sebagaimana disebutkan oleh Turner, juga membuat postulat hukum sejarah perkembangan manusia dari basis teologis menuju ke basis positivis. $^{5}$

August Comte (1798-1857) adalah rekan kerja dan asisten Saint Simon. Comte mengembangkan suatu pengetahuan baru yang disebutnya sebagai fisika sosial. Kemudian pada tahun 1839, Comte mengubah fisika sosial menjadi sosiologi. Comte berupaya membangun sosiologi dengan mengikuti metode ilmu-ilmu alam.

Dengan berbasis pada metode ilmu alam, Comte berharap sosiologi sebagai ilmu yang baru lahir bisa maju dan terdepan di antara ilmu-ilmu yang bukan ilmu alam. Comte kemudian merumuskan evolusi manusia dalam tiga tahap, yaitu tahap teologi, tahap metafisika, dan tahap tertinggi, yaitu ilmu positif dengan sosiologi sebagai puncak.

Setelah Comte, sosiologi dikembangkan oleh Emile Durkheim (1858-1917). Mirip dengan pandangan Comte, Durkheim berpandangan bahwa sosiologi harus berorientasi kepada penelitian empiris. Dengan orientasi itu, sosiologi bisa mendapat "tempat" di antara filsafat dan ilmu-ilmu lainnya. ${ }^{6}$ Bagi Durkheim, Comte dan Herbert Spencer lebih cenderung ke arah pemikiran filsafat dalam mengembangkan sosiologi.

Durkheim menyatakan bahwa pokok bahasan sosiologi adalah studi atas fakta sosial. Fakta sosial itu berupa struktur sosial, norma budaya, dan nilai yang berada

\footnotetext{
${ }^{4}$ Turner, "The Origins of Positivism: The Contributions of Auguste Comte and Herbert Spencer" dalam George Ritzer and Barry Smart (eds), Handbook of Social Theory, hlm. 31.

${ }^{5}$ Turner, "The Origins of Positivism: The Contributions of Auguste Comte and Herbert Spencer" dalam George Ritzer and Barry Smart (eds), Handbook of Social Theory, hlm. 31.

${ }^{6}$ George Ritzer, Sociological Theory, New York: McGraw Hill, 2009, hlm. 77.
} 
di luar dan memaksa aktor. Fakta sosial harus dipelajari secara empiris, yaitu melalui observasi dan eksperimen. ${ }^{7}$ Fakta sosial, karena berada di luar pikiran, dengan sendirinya berbeda dengan psikologi (yang lebih melihat pada dorongan internal dari individu). ${ }^{8}$

John Stuart Mill, seorang filsuf naturalis dari Inggris, juga punya pandangan yang mirip dengan Comte dan Durkheim. Mill, sebagaimana disebutkan oleh Gadamer, mengatakan bahwa metode induktif adalah dasar dari semua ilmu eksperimental, termasuk ilmu humaniora. Ilmu humaniora juga mencari kesamaan, keteraturan, dan konformitas terhadap hukum yang memungkinkan untuk memprediksi fenomena dan proses sosial. ${ }^{9}$

Gagasan positivisme dan perkembangan ilmu baru, yaitu sosiologi, perlahan-lahan mendominasi khazanah ilmu-ilmu humaniora. Dominasi itu akhirnya direspons dan dilawan oleh sejumlah filsuf yang menganggap bahwa positivisme mengabaikan dimensi manusia yang begitu kompleks yang berbeda sama sekali dengan obyek penelitian ilmu-ilmu alam.

\subsection{Methodenstreit (Perdebatan tentang Metode)}

Positivisme memang telah memengaruhi dan mendominasi perkembangan ilmuilmu kemanusiaan, tetapi mulai muncul gugatan atas dominasi positivisme. Di Jerman pada abad ke-19 terjadi Methodenstreit atau perdebatan tentang metode yang mempunyai dua tujuan, yaitu pertama, melawan dominasi positivisme dan kedua, mencari fondasi bagi pengembangan metode ilmu-ilmu di luar ilmu alam. Menurut Lydia Patton, salah satu faktor yang mendorong terjadinya Methodenstreit di Jerman adalah pembaruan sistem universitas di Jerman (Prusia), yang dimulai di

\footnotetext{
${ }^{7}$ Ritzer, Sociological Theory, hlm. 77.

${ }^{8}$ Ritzer, Sociological Theory, hlm. 78.

${ }^{9}$ Diambil dari Hans-Georg Gadamer, Truth and Method, London: Continuum, 2004, hlm. 3.
} 
Universitas Berlin pada tahun $1810 .^{10}$ Wilhelm von Humboldt, Fichte, dan Schleiermacher memandang universitas sebagai wahana untuk mengembangkan ide partikular dari Wissenschaft (ilmu). Karya-karya Comte dan Mill juga mulai diterjemahkan dan didiskusikan. ${ }^{11}$

Berikut adalah sejumlah perdebatan mengenai metodologi bagi perkembangan ilmu-ilmu kemanusiaan. Di bidang kajian sejarah, sejarawan Johann Gustav Droysen (1808-1884) mengkritik pandangan sejarawan positivis dari Inggris, Henry Thomas Buckle (1821-1862). Buckle mempunyai pandangan sejarah manusia yang deterministik karena bagi Buckle, perilaku manusia sama seperti gerak planet dan obyek alam lainnya. Droysen mengkritik Buckle dengan mengajukan independensi metode ilmu sejarah. Droysen menyebutkan metode sejarah adalah Verstehen (untuk memahami). ${ }^{12}$

Debat metodologi juga terjadi antara Wilhelm Windelband dan Heinrich Rickert dari mazhab Baden ${ }^{13}$ dan Wilhelm Dilthey. Sebenarnya Windelband dan Rickert di satu pihak dan Dilthey di pihak lain mempunyai sikap yang sama berhadapan dengan aliran positivisme. Kedua belah pihak sama-sama menganggap bahwa humaniora tidak harus menggunakan metode ilmu alam seperti yang diinginkan oleh kaum positivis. Namun, kedua belah pihak punya pandangan yang berbeda mengenai metode apa yang paling sesuai untuk ilmu-ilmu non-ilmu alam. ${ }^{14}$

Methodenstreit juga terjadi di ilmu ekonomi. Yang terlibat dalam Methodenstreit adalah Carl Menger, tokoh utama mazhab ekonomi Austria, yang berhadapan

\footnotetext{
${ }^{10}$ Lydia Patton, "Methodology of the Sciences" dalam Michael Forster and Kristin Gjesdal (ed), The Oxford Handbook of German Philosophy in the Nineteenth Century, Oxford: Oxford University Press, 2015, hlm. 595. ${ }^{11}$ Lydia Patton, "Methodology of the Sciences" dalam Michael Forster and Kristin Gjesdal (ed), The Oxford Handbook of German Philosophy in the Nineteenth Century, hlm. 595.

${ }^{12}$ Lydia Patton, "Methodology of the Sciences" dalam Michael Forster and Kristin Gjesdal (ed), The Oxford Handbook of German Philosophy in the Nineteenth Century, hlm. 602-603.

${ }^{13}$ Ada dua mazhab yang mendominasi pemikiran Neo-Kantian, yaitu mazhab Baden yang berpusat di Universitas Heidelberg dan Freiburg di wilayah Baden, Jerman barat daya, dan mazhab Marburg dari Universitas Marburg. Tokoh dari mazhab Baden ialah Windelband, Rickert, dan Lask, sementara tokoh dari mazhab Marburg ialah Cohen, Natorp, dan Cassirer.

${ }^{14}$ Lihat Gadamer, Truth and Method, hlm. XXVI.
} 
dengan Gustav Schmoller, salah satu tokoh dari mazhab sejarah ekonomi Jerman. Pada tahun 1883, Menger menerbitkan buku yang berjudul Problems of Economics and Sociology. Buku itu di-review oleh Schmoller dan kemudian ditanggapi balik oleh Menger.

Perdebatan di antara kedua belah pihak tidak lepas dari pandangan yang berbeda dari kedua mazhab ekonomi tersebut. Mazhab sejarah ekonomi Jerman terdiri dari Wilhelm Roscher, Karl Knies, Bruno Hildebrand, dan Schmoller. Mazhab ini berpandangan bahwa ekonomi adalah bagian dari studi yang lebih luas dan integral tentang masyarakat. Bagi mereka, upaya untuk menemukan "hukum-hukum umum" tentang ekonomi adalah suatu hal yang keliru dan harus ditolak. ${ }^{15}$

Mazhab ekonomi Austria berpandangan bahwa asumsi satu-satunya yang menggerakkan ekonomi adalah keserakahan atau kepentingan diri. Mereka mendasarkan diri pada pemikiran ekonomi dari Adam Smith dan David Ricardo. Keserakahan atau kepentingan diri itulah yang menjadi dasar hukum ekonomi. Menger berpendapat bahwa tujuan ilmu ekonomi adalah mendirikan hukum-hukum ekonomi yang eksak seperti hukum-hukum umum yang berlaku di fisika. ${ }^{16}$

Roscher dan rekan-rekan mengkritik hukum umum ekonomi yang didasari oleh asumsi keserakahan. Kebenaran hukum ekonomi semacam itu tidak bisa berlaku universal karena masyarakat berubah. Roscher dan kawan-kawan mengusulkan agar mazhab ekonomi Austria mengubah metode deduksinya menjadi metode induksi karena penelitian ekonomi harus didasarkan pada data empiris dan analisis yang hati-hati. ${ }^{17}$

\footnotetext{
15 Kyung-Man Kim, “Max Weber's Axiological Critique of the Methodology of the Human Sciences: The Methodenstreit and Ideal Types” dalam Korean Journal of Sociology, Vol. 42, No. 4, Juni 2008, hlm. 101.

16 Kyung-Man Kim, "Max Weber's Axiological Critique of the Methodology of the Human Sciences: The Methodenstreit and Ideal Types” dalam Korean Journal of Sociology Vol. 42, No. 4, Juni 2008, hlm. 102.

${ }^{17}$ Kyung-Man Kim, "Max Weber's Axiological Critique of the Methodology of the Human Sciences: The Methodenstreit and Ideal Types” dalam Korean Journal of Sociology, Vol. 42, No. 4, Juni 2008, hlm. 101.
} 


\subsection{Kritik Gadamer atas Pembakuan Metodologi Humaniora}

Gadamer punya sikap sendiri terhadap perdebatan metodologi. Gadamer menentang kubu kaum positivis yang mengunggulkan metodologi ilmu-ilmu alam untuk digunakan sebagai metode memahami masyarakat. Namun, Gadamer juga bersikap kritis terhadap kubu yang mempromosikan kekhususan metodologi ilmuilmu kemanusiaan seperti yang diusung oleh Helmholtz, Windelband, dan Dilthey. Bagi Gadamer, kedua kubu, meski saling berdebat, tetap percaya pada kekuatan metodologi sebagai jalan mencapai kebenaran.

Sebelum terbitnya TM, Gadamer telah lama mempunyai sikap kritis terhadap penggunaan metode dalam memahami teks-teks. Ketika Gadamer masuk ke dalam dunia filologi, Gadamer berhadapan dengan kecenderungan umum yang dipakai oleh banyak filolog, yaitu tendensi Altertumswissenschaft atau upaya memahami teks-teks dari masa Yunani klasik dengan kerangka ilmu. Gadamer tidak ingin mengikuti kecenderungan tendensi Altertumswissenschaft karena bagi Gadamer Altertumswissenschaft mengabaikan konteks para penulis teks di masa Yunani klasik.

Kritik Gadamer terhadap dominasi penggunaan metodologi sebagai jalan mencari kebenaran memuncak pada TM. Pada TM, Gadamer mengkritik para filsuf, sejarawan, ilmuwan, dan ahli hermeneutika yang meyakini bahwa hanya melalui metodologi (baik yang pro pada metodologi ilmu-ilmu alam maupun yang pro pada metodologi yang khusus untuk ilmu-ilmu kemanusiaan), manusia dapat mencapai kebenaran.

Berikut adalah uraian kritik Gadamer terhadap beberapa intelektual yang percaya pada metodologi sebagai jalan yang tepat untuk mencari kebenaran. Kritik pertama dilancarkan oleh Gadamer terhadap sejarawan seperti Ranke dan Droysen yang berupaya untuk mempromosikan metodologi dalam pengembangan sejarah. 
Selanjutnya adalah kritik Gadamer terhadap Dilthey yang ingin menjadikan hermeneutika sebagai pengetahuan yang didasarkan pada metodologi yang khas.

\subsection{Kritik Gadamer atas Metode Sejarah dari Ranke dan Droysen}

Gadamer mempunyai minat terhadap sejarah. Minat tersebut dituangkan Gadamer dalam salah satu bab dari buku TM. Dalam bab mengenai sejarah, Gadamer melihat bahwa para sejarawan terkemuka juga tidak luput dari upaya untuk mencari dan menjunjung tinggi metodologi dalam pembahasan sejarah. Ada beberapa tokoh sejarawan yang dibahas. Tulisan ini akan menyorot kritik Gadamer atas dua sejarawan penting, yaitu Leopold von Ranke dan Johann Gustav Droysen.

Gadamer memasukkan Ranke dan Droysen ke dalam mazhab historis. Kemunculan mazhab historis tidak lepas dari perdebatan antara kubu yang mengandalkan pada filsafat sejarah untuk mengembangkan historiografi dan kubu yang menolak skema filsafat sejarah. Menurut Gadamer, pandangan sejarah dari mazhab historis tidak bisa lepas dari pengaruh pemikiran Herder yang mempunyai sikap kritis terhadap kaum pencerahan yang menekankan akal budi sebagai jalan manusia mencapai kemajuan di bidang ilmu pengetahuan.

Herder mengingatkan bahwa memahami hubungan masa lalu dengan masa kini tidak bisa diandalkan pada filsafat sejarah yang berwatak teleologis. Herder melihat hubungan dialektis dalam berbagai peristiwa di masa lalu yang bisa menjadi contoh dan tidak bisa diulang. Herder menyatakan bahwa berpikir historis berarti mengakui bahwa masing-masing periode sejarah mempunyai kebenarannya sendiri. ${ }^{18}$

Mazhab historis menolak adanya unsur apriori dalam sejarah. Unsur apriori itu bisa berupa ide, ada (being), atau kebebasan yang oleh beberapa sejarawan dianggap

\footnotetext{
${ }^{18}$ Gadamer, Truth and Method, hlm. 198.
} 
sebagai penentu jalannya sejarah yang universal. ${ }^{19}$ Bagi mereka, sejarah bukanlah suatu perjalanan yang utuh tetapi lebih pada fragmen-fragmen historis. Karena itu, sejarah harus dipelajari melalui penelitian sejarah, bukan filsafat. Dengan penelitian sejarah, kita bisa memahami sejarah dengan lebih baik. ${ }^{20}$

Ranke dan Droysen sama-sama menginginkan adanya penelitian sejarah dengan menggunakan metodologi, tetapi Ranke lebih condong menginginkan penelitian sejarah menggunakan metodologi seperti metodologi ilmu-ilmu alam, sedangkan Droysen lebih menekankan pada kekhasan metodologi humaniora yang berbeda dengan metodologi ilmu-ilmu alam.

Ranke, yang lahir di Jerman pada tahun 1795, adalah seorang sejarawan yang diakui sebagai salah satu sejarawan besar yang memengaruhi perkembangan studi sejarah (historiografi) sebagai suatu disiplin ilmu yang ketat seperti ilmu-ilmu lainnya. Ranke belajar sejarah di Universitas Berlin. Ketika itu di Universitas Berlin ada pertentangan di antara dua kubu yang berupaya untuk mencari pemahaman sejarah yang paling memadai. Kubu pertama adalah Hegel dan pengikutnya yang menekankan filsafat sejarah sebagai jalan yang tepat untuk memahami sejarah. Kubu kedua adalah Friedrich Schleiermacher dan Carl von Savigny yang bersandar pada filologi untuk menjelaskan sejarah. Ranke memihak kubu Schleiermacher dan Savigny, dan Ranke menjalin persahabatan dengan Schleiermacher. ${ }^{21}$

Ranke berusaha menegakkan historiografi yang obyektif untuk melawan kecenderungan historiografi di masa sebelumnya yang lebih terpengaruh dengan filsafat sejarah yang spekulatif. Ranke ingin membuat penelitian sejarah yang baru dengan didasarkan pada landasan metodologis yang ketat. ${ }^{22}$ Menurut Ranke, sejarah

\footnotetext{
${ }^{19}$ Ranke dan Droysen menolak pandangan Hegel mengenai konsep kesatuan dunia historis melalui konsep ide. Lihat Gadamer, Truth and Method, hlm. 206-207.

${ }^{20}$ Gadamer, Truth and Method, hlm. 199.

${ }^{21}$ Katherina Kinzel, "Method and Meaning: Ranke and Droysen on the Historian's Disciplinary Ethos" dalam History and Theory Vol. 59, No. 1, Maret 2020, hlm. 22-41.

${ }^{22}$ Katherina Kinzel, "Method and Meaning: Ranke and Droysen on the Historian's Disciplinary Ethos" dalam History and Theory Vol. 59, No. 1, Maret 2020, hlm. 22-41.
} 
mengandung unsur kebebasan. Banyak peristiwa sejarah ditentukan oleh pikirianpikiran orisinal yang membuat sekaligus mengubah perjalanan sejarah. Ranke memang menekankan soal kebebasan dalam sejarah tetapi juga menyatakan bahwa kebebasan itu terkait dengan kekuasaan. Tak mungkin kebebasan bisa ada sepenuhnya tanpa ada kekuasaan. Sebaliknya kekuasaan juga mengandung kebebasan. Menurut Ranke, tak ada kontradiksi soal kebebasan yang dibatasi atau dengan kata lain di samping kebebasan ada keniscayaan. ${ }^{23}$

Untuk mendukung klaimnya, Ranke menekankan sejarah sebagai "growing sum"24 dengan merujuk pada kemajuan yang dicapai oleh peradaban Barat. Maksudnya adalah peradaban Barat bisa maju karena kontinuitas kemajuan historis yang dimulai dari peradaban Yunani, Romawi, sampai zaman Kristen yang pada akhirnya membentuk peradaban Barat yang maju. Ranke berupaya untuk menyusun metodologi ilmu sejarah yang didasarkan pada penelitian sejarah sekaligus menolak unsur apriori (ide, ada). Salah satu lawan terbesar Ranke dalam pengembangan ilmu sejarah adalah pemikiran filsafat sejarah dari Hegel. Namun, upaya Ranke membedakan diri dan mengkritik pandangan sejarah dari Hegel di mata Gadamer tidaklah memadai.

Penekanan Ranke pada pikiran-pikiran orisinal dalam sejarah sangat mirip dengan pandangan Hegel mengenai individu-individu historis yang memengaruhi jalannya sejarah. ${ }^{25}$ Pemikiran Ranke tentang growing sum dalam sejarah seperti kemajuan dari peradaban Barat mirip dengan penjelasan Hegel mengenai perjalanan roh sejarah yang berpuncak pada negara Prusia sebagai wujud dari roh historis yang tertinggi. Kritik utama Gadamer adalah upaya Ranke yang mengunggulkan peradaban Barat sebenarnya terkait dengan aspek filosofis sehingga penolakan tehadap filsafat sejarah oleh Ranke terasa janggal. ${ }^{26}$

\footnotetext{
${ }^{23}$ Gadamer, Truth and Method, hlm. 203.

${ }^{24}$ Gadamer, Truth and Method, hlm. 204.

${ }^{25}$ Gadamer, Truth and Method, hlm. 201.

${ }^{26}$ Gadamer, Truth and Method, hlm. 206.
} 
Tokoh kedua dari mazhab historis adalah Droysen, sejarawan besar dari Jerman. Dia menulis biografi Alexander Agung dan masa keemasan Hellenisme. Menurut Droysen, ilmu-ilmu alam memang telah mencapai kemajuannya, tetapi ilmu sejarah harus mengembangkan metodenya sendiri. Droysen mengusulkan agar ilmu sejarah tidak mengadopsi pandangan positivisme karena positivisme ingin menyubordinasi ilmu sejarah ke dalam ilmu-ilmu alam. ${ }^{27}$

Droysen menyadari kelemahan dari pendekatan historis yang empiris dari Ranke sehingga Droysen tidak menolak asumsi filosofis dalam ilmu sejarah. Droysen menggunakan konsep kekuatan-kekuatan moral sebagai unsur penting dalam sejarah. Droysen juga memperbaiki konsep individu historis dari Ranke dengan menyatakan bahwa individu bisa disebut mempunyai peran dalam sejarah jika individu tersebut menaikkan kekuatan moralnya. ${ }^{28}$ Lebih lanjut Droysen menyatakan bahwa individu yang bermoral tinggi tersebut haruslah berjalan bersama dengan individu yang lain untuk mencapai tujuan bersama.

Droysen, sebagaimana disebutkan oleh Gadamer, menyatakan bahwa kita tidak bisa melihat tujuan akhir dari sejarah. Yang bisa kita lihat adalah tujuan dari gerakan kita dalam peristiwa-peristiwa sejarah. Tujuan akhir sejarah itu hanya bisa dicapai melalui aktivitas langsung tanpa henti dari manusia, bukan karena kekuatan dari pengetahuan historis. $^{29}$

Formula Droysen tentang sejarah adalah memahami sejarah melalu penelitian. Moto Droysen adalah "penelitian, tidak ada yang lain kecuali penelitian". Itulah metode sejarah dari Droysen sekaligus menunjukkan perbedaan dengan penggunaan eksperimen dalam ilmu alam. ${ }^{30}$ Menurut Gadamer, Droysen mempunyai kesulitan dalam memberikan penjelasan yang memadai mengenai metode penelitian historis

\footnotetext{
27 Jean Grondin, Introduction to Philosophical Hermeneutics trans. Joel Weinsheimer, New Haven: Yale University Press, 1994, hlm. 80.

${ }^{28}$ Gadamer, Truth and Method, hlm. 210.

${ }^{29}$ Gadamer, Truth and Method, hlm. 211.

${ }^{30}$ Gadamer, Truth and Method, hlm. 212.
} 
jika dibandingkan dengan metode eksperimen di ilmu-ilmu alam. Gadamer juga mempersoalkan bagaimana faktor kekuatan moral bisa diketahui melalui metode penelitian historis. ${ }^{31}$

\subsection{Kritik Gadamer atas Metodologi Hermeneutika Dilthey}

Wilhem Dilthey (1833-1911) pada awalnya belajar teologi di Universitas Heidelberg, kemudian melanjutkan kuliah filsafat di Universitas Berlin. Dilthey mendapat banyak pengaruh dari Schleiermacher di bidang hermeneutik dan pandangan sejarah dari Droysen. Dilthey mengembangkan pembedaan metode proses mengetahui dari Droysen. Menurut Dilthey, obyek studilah yang membuat perbedaan antara Naturwissenschaften (ilmu-ilmu alam) dan ilmu humaniora yang disebutnya Geisteswissenschaften. Obyek studi dari Naturwissenschaften adalah benda-benda alam, sedangkan obyek studi Geisteswissenschaften adalah segi batin manusia.

Menurut Bakker, pandangan Dilthey mengenai Geist dipengaruhi oleh John Stuart Mill. Mill menyebut ilmu-ilmu yang bukan ilmu alam sebagai moral science, yang dalam bahasa Jerman adalah Geist. Metode yang digunakan oleh Mill dalam moral science adalah metode individualisme. Bagi Mill, memahami masyarakat harus dimulai dari observasi atas individu yang selalu memaksimalkaan manfaat bagi dirinya sendiri (utilitarianisme). Dilthey mengagumi pandangan Mill, tetapi Dilthey menolak gagasan individual yang utilitarian dari Mill. Dilthey melihat individu sebagai manusia yang seutuhnya. ${ }^{32}$

Dalam karyanya yang berjudul Introduction to the Human Sciences, ${ }^{33}$ Dilthey, sebagaimana disebutkan oleh Grondin, menyatakan bahwa dia ingin memberikan

\footnotetext{
${ }^{31}$ Gadamer, Truth and Method, hlm. 212

32 J.I. (Hans) Bakker, "Wilhelm Dilthey: Classical Sociological Theorist” dalam Quartely Journal of Ideology, 10 Mei 1998, hlm. 47-48.

${ }^{33}$ Pada awalnya judul tulisannya adalah Critique of Historical Reason. Perubahan judul mungkin karena Dilthey ingin menegaskan kekhasan dan kekuatan metodologi humaniora yang berbeda dengan metodologi ilmu-ilmu alam.
} 
legitimasi epistemologi dari humaniora sebagai suatu ilmu pengetahuan. Tujuan Dilthey adalah membuat humaniora sebagai ilmu-ilmu pengetahuan yang otonom dan melindungi humaniora dari perambahan ilmu-ilmu alam dengan metodenya, melepaskan diri dari subordinasi ilmu-ilmu alam. Dengan demikian, humaniora berdiri sejajar dengan ilmu-ilmu alam. ${ }^{34}$

Menurut Dilthey, sebagaimana disebutkan oleh Grondin, metodologi humaniora harus didasarkan pada penelitian psikologi karena humaniora itu berkaitan dengan fakta-fakta kesadaran yang harus dibuat koherensinya dan divalidasi oleh struktur apriori dalam kesadaran manusia. Proses itulah yang disebut dengan Verstehen (memahami). Dilthey, sebagaimana disebutkan oleh Grondin, dalam karyanya yang berjudul Ideas Concerning Descriptive and Analytic Psychology menawarkan fondasi psikologi untuk pengembangan humaniora. ${ }^{35}$

Dilthey mengajukan Verstehen sebagai metode Geisteswissenschaften untuk membedakan diri dengan Erklären (menjelaskan) yang merupakan metode ilmuilmu alam. Kalau Erklären dipakai untuk memahami obyek di alam, melalui Verstehen, Dilthey berupaya memahami pemikiran orang lain. Dilthey mempunyai cara yang berbeda dengan Schleiermacher dalam memahami pikiran orang. Bagi Schleiermacher, memahami pemikiran orang dengan membayangkan diri kita sebagai orang lain, sedangkan Dilthey memahami batin manusia melalui interpretasi. ${ }^{36}$

Pemikiran Dilthey mengalami perkembangan terkait dengan munculnya Husserl dengan pemikiran fenomenologisnya. Dilthey kemudian mengaitkan psikologinya dengan gagasan keterarahan manusia untuk mencari makna bagi hidupnya. Penyelidikan historis adalah penyelidikan mencari makna. Namun, Dilthey punya

\footnotetext{
${ }^{34}$ Jean Grondin, Introduction to Philosophical Hermeneutics trans. Joel Weinsheimer, New Haven: Yale University Press, 1994, hlm. 84.

35 Jean Grondin, Introduction to Philosophical Hermeneutics trans. Joel Weinsheimer, New Haven: Yale University Press, 1994, hlm. 85.

${ }^{36}$ Richard E. Palmer, Hermeneutics: Interpretation Theory in Schleiermacher, Dilthey, Heidegger, and Gadamer, Illinois: Northwestern University Press, 1969, hlm. 104.
} 
pandangan yang berbeda dengan Husserl soal makna. Husserl mencari makna melalui investigasi logika murni, sedangkan Dilthey lebih kepada suatu bentuk ekspresi kehidupan. ${ }^{37}$

Dilthey mempunyai sikap yang sama dengan Ranke dan Droysen soal kritik atas pemikiran filsafat sejarah dari Hegel. Namun, ternyata, menurut Gadamer, Dilthey tidak berbeda jauh dengan Ranke dan Droysen pada akhirnya tidak bisa membuat demarkasi yang ketat dengan pemikiran Hegel. Sejumlah pokok pikiran Dilthey mempunyai kemiripan dengan Hegel meski Dilthey berupaya sekeras mungkin untuk membedakan diri dari Hegel. Menurut Gadamer, di masa tuanya, Dilthey mempunyai skema penafsiran yang dipahami sebagai roh, ${ }^{38}$ padahal unsur roh adalah inti dari filsafat sejarahnya Hegel.

Gadamer juga melihat bahwa kendati Dilthey berupaya untuk melawan relativisme sejarah, Dilthey percaya pada obyektivisme sejarah, tetapi dalam berbagai argumen yang diajukannya, ternyata pandangan Dilthey juga tidak bebas dari relativisme. ${ }^{39}$ Gadamer juga menganggap bahwa prosedur induksi yang digunakan oleh Dilthey (dipinjam dari metode ilmu-ilmu alam) tidak tepat untuk memahami pengalaman historis. Seorang peneliti sejarah tidak mudah mengambil kesimpulan umum dari pengalaman-pengalaman historis yang khusus seperti yang diyakini oleh Dilthey. ${ }^{40}$

\section{Revitalisasi Humanisme}

Gadamer melihat bahwa ada yang hilang dalam pembicaraan tentang perkembangan ilmu pengetahuan, yaitu gagasan humanisme yang sebenarnya mempunyai akar historis yang panjang dalam peradaban Barat. Pihak-pihak yang terlibat dalam perdebatan metodologi mengabaikan peran humanisme bagi perkembangan pengetahuan modern. Pada bagian

\footnotetext{
${ }^{37}$ Jean Grondin, Introduction to Philosophical Hermeneutics trans. Joel Weinsheimer, hlm. 219-220.

${ }^{38}$ Gadamer, Truth and Method, hlm. 222.

${ }^{39}$ Gadamer, Truth and Method, hlm. 230.

${ }^{40}$ Gadamer, Truth and Method, hlm. 234.
} 
awal TM, Gadamer menawarkan diskursus humanisme di tengah kepungan dominasi metodologi untuk mengembangkan humaniora. Bagi Gadamer, metodologi tidak cukup untuk memahami dimensi kehidupan manusia yang begitu kompleks.

Gadamer mengangkat empat konsep penting dari tradisi humanisme, yaitu Bildung, sensus communis, pertimbangan, dan selera. Keempat konsep ini lebih banyak digunakan di bidang etika dan estetika. Keempat konsep itu populer di abad ke-19 dan banyak dibahas oleh para filsuf moral, ahli retorika, penggiat seni, dan teolog dari Inggris dan Jerman.

\subsection{Bildung}

Konsep Bildung dalam kepustakaan intelektual Jerman telah mendapat banyak perhatian dari kalangan filsuf, seniman, sastrawan, dan sejarawan. Tokoh yang mengawali pembicaraan mengenai konsep Bildung adalah Johann Gottfried Herder (1744-1803), seorang filsuf, teolog, penyair sekaligus kritikus sastra dari Jerman. Herder menekuni studi bahasa Jerman, dan dia melihat bahwa bahasa selama ini hanya dipahami sebagai alat untuk mengekspresikan pengetahuan. Herder menyatakan bahwa bahasa berfungsi untuk membentuk kesadaran diri (Selbsúbewusstsein). Herder memaknai bahasa sebagai konstruksi yang dalam bahasa Jerman disebut dengan Bildung. Bildung adalah tujuan sesungguhnya dari bahasa. ${ }^{41}$

Pandangan Herder tentang Bildung telah memberikan sumbangan penting di berbagai bidang. Konsep Bildung digunakan oleh sebagian filologi klasik untuk menafsirkan teks-teks dari masa Yunani klasik. Di bidang seni, konsep Bildung digunakan sebagian penyair untuk mencari identitas diri dan identitas kolektif. Di bidang pendidikan, Bildung dipakai sebagai landasan untuk mendidik anak-anak muda

\footnotetext{
${ }^{41}$ Robert R. Sullivan, Political Hermeneutics: The Early Thinking of Hans-Georg Gadamer, Pennsylvania: The Pennsylvania State University Press, 1989, hlm. 20-21.
} 
Jerman. Konsep Bildung juga digunakan di bidang politik oleh Humboldt, Fichte, dan Hegel yang memakai konsep Bildung untuk menganalisis politik Jerman. ${ }^{42}$

Menurut Sullivan, Gadamer mulai mengenal konsep Bildung dari The Stefan George Circle yang adalah suatu kelompok seniman muda yang dipimpin oleh Stefan George, seorang penyair terkenal di Jerman. Gadamer menggemari seni dan diajak untuk bergabung dalam The Stefan George Circle. ${ }^{43}$ Gadamer kemudian mengembangkan konsep Bildung dalam TM sebagai salah satu konsep humanisme melawan pengaruh metodologi. Gadamer menyatakan bahwa dia beruntung pada masanya konsep Bildung masih banyak dipakai dan telah mewarnai pengembangan berbagai bidang pengetahuan di Jerman. Pada awalnya konsep Bildung lebih diartikan sebagai bentuk fisik manusia, bentuk susunan alam seperti gunung (Gebirgsbildung). Berkat Herder, istilah Bildung menjadi lebih kaya. Bildung lebih sering digunakan untuk merujuk pada kebudayaan. ${ }^{44}$

Pandangan Herder mengenai Bildung kemudian dikembangkan oleh Kant dan Hegel. Kant memang tidak menggunakan isilah Bildung, tetapi Kant mengartikan kebudayaan sebagai suatu tindakan bebas manusia untuk mengembangkan dirinya. Hegel menggunakan istilah Sichbilden (mendidik diri sendiri) dan Bildung, yang berarti suatu karakter pemikiran yang lebih tinggi dan dengan totalitas intelektual dan moral. Bildung mengingatkan pada tradisi mistik dari zaman klasik ketika manusia membawa citra Tuhan dalam dirinya. ${ }^{45}$

Hegel kemudian merumuskan Bildung dalam kaitan dengan perkembangan kehidupan manusia. Manusia dicirikan dengan terputusnya dirinya secara langsung dengan kondisi alamiah. Dalam keterputusan itulah Bildung menjadi faktor penting. Di titik ini terjadi peningkatan dari yang partikular ke universal. Dalam tahap itu

\footnotetext{
${ }^{42}$ Robert R. Sullivan, Political Hermeneutics: The Early Thinking of Hans-Georg Gadamer, hlm. 24.

${ }^{43}$ Robert R. Sullivan, Political Hermeneutics: The Early Thinking of Hans-Georg Gadamer, hlm. 29-30.

${ }^{44}$ Gadamer, Truth and Method, hlm. 9.

${ }^{45}$ Gadamer, Truth and Method, hlm. 9-10.
} 
manusia menunda atau membatasi hasrat sekaligus memperoleh kebebasan terhadap hasrat tersebut. ${ }^{46}$

Lebih lanjut Hegel menyatakan bahwa ciri khas dari Bildung adalah membiarkan diri terbuka terhadap yang lain, terbuka terhadap sudut pandang yang universal. Namun, bukan berarti bahwa seseorang tunduk sepenuhnya kepada yang lain. Sudut pandang yang lain merupakan suatu kemungkinan bagi pengembangan seseorang. ${ }^{47}$

Helmholz juga mempunyai pandangan mengenai Bildung. Helmholz berpandangan bahwa unsur memori (yang harus dimiliki oleh sejarawan dan kritikus sastra) merupakan Bildung yang membantu pengembangan pengetahuan manusia, khususnya humaniora.

Gadamer terkesan dengan pandangan Hegel mengenai Bildung. Gadamer menyetujui penekanan Hegel soal kesediaan seseorang untuk membuka diri terhadap orang lain, terhadap pandangan yang universal. Namun, Gadamer keberatan dengan pandangan Hegel yang menyatakan bahwa pengembangan diri manusia secara penuh hanya bisa melalui proses penalaran filosofis. ${ }^{48}$ Bagi Gadamer, ada banyak faktor yang memungkinkan proses Bildung bisa tercapai.

Keberatan Gadamer terhadap Helmholz ialah Helmholz membatasi Bildung pada psikologi, yaitu bagaimana manusia bisa menjaga dan mengembangkan memorinya. Bagi Gadamer, kapasitas memori (mengingat, melupakan, mengingat kembali) tidak sekadar suatu bentuk kecerdasan tertentu, tetapi lebih berkaitan dengan proses pengembangan manusia itu sendiri.

\subsection{Sensus Communis}

\footnotetext{
${ }^{46}$ Gadamer, Truth and Method, hlm. 11

${ }^{47}$ Gadamer, Truth and Method, hlm. 15-16.

${ }^{48}$ Gadamer, Truth and Method, hlm. 13.
} 
Gadamer memulai pembahasan mengenai sensus communis dari pandangan Giambattista Vico (1668-1744), seorang filsuf, ahli retorika, dan ahli hukum dari Italia. Dalam karyanya yang berjudul De nostri temporis studiorum ratione, Vico mempromosikan sistem pendidikan Jesuit yang sangat bernuansa humanis. Vico mempertahankan humanisme dari pengaruh Jansenisme dan pemikiran Descartes. ${ }^{49}$

Bagi Vico, humanisme adalah sistem pengetahuan baru yang didasarkan pada kebenaran dari masa klasik. Vico menganggap sensus communis itu seperti eloquentia (berbicara dengan baik) seperti yang sering digunakan oleh para ahli retorika. Eloquentia mempunyai dua makna. Makna pertama adalah seni berbicara, sementara makna kedua adalah berkata tentang sesuatu yang benar. ${ }^{50}$

Salah satu tokoh di zaman Yunani klasik yang dirujuk oleh Vico sebagai inspirasi membuat cara filsafat yang baru adalah Sokrates. Vico melihat cara sinikal Sokrates menghadapi para filsuf di zamannya (khususnya para Sofis) yang lebih mengutamakan penguasan teori-teori. Vico mengkritik kaum Stoa yang percaya pada rasio sebagai penentu segalanya (regula veri). Vico lebih setuju pada para pemikir klasik yang menyatakan bahwa ketidaktahuan adalah pengetahuan yang lebih baik. ${ }^{51}$

Penekanan Vico pada sensus communis mengandung tradisi humanis yang kuat. Pada abad ke-17 ada debat di Prancis mengenai querelle des anciens et des modernes, khususnya di bidang seni dan kesusastraan. Perdebatannya mengenai apa hubungan antara seni-sastra modern dan praktik-praktik yang bijaksana dari zaman Yunani klasik. Perdebatan itu memengaruhi Vico ketika dia membicarakan bagaimana peran praktik dari masa Yunani klasik terhadap perkembangan pengetahuan modern di Eropa pada abad ke-18. Vico tidak menyangkal kemajuan yang dicapai oleh pengetahuan modern, tetapi Vico menunjukkan keterbatasan dari pengetahuan modern. ${ }^{52}$

\footnotetext{
${ }^{49}$ Gadamer, Truth and Method, hlm. 17.

${ }^{50}$ Gadamer, Truth and Method, hlm. 17.

${ }^{51}$ Gadamer, Truth and Method, hlm. 18.

52 Gadamer, Truth and Method, hlm. 18.
} 
Vico membuat analogi pembedaan sensus communis dengan pengetahuan modern itu seperti Aristoteles membedakan pengetahuan teoretis dengan phronesis. Phronesis adalah jenis pengetahuan yang berbeda. Phronesis berkaitan dengan pengetahuan praktis yang mengarah ke situasi konkret. ${ }^{53}$ Sensus communis seperti phronesis adalah suatu pengetahuan yang berbeda, tidak lebih rendah daripada pengetahuan modern yang berbasis pada metodologi.

Vico mengartikan sensus communis sebagai perasaan seseorang tentang yang benar dan ada kebaikan umum yang ditemukan pada semua manusia. Vico tidak memaksudkan sensus communis sebagai suatu atribut yang abstrak, tetapi lebih sebagai atribut nyata yang mengikatkan manusia pada komunitasnya, baik kelompok, masyarakat, bangsa, maupun seluruh umat manusia. ${ }^{54}$

Menurut Gadamer, pandangan Vico sebenarnya menghidupkan kembali cara berfilsafat dari Sokrates yang kritis terhadap para Sofis yang sangat mengandalkan kekuatan teori. Lebih lanjut, Gadamer menyatakan pembelaan Vico atas sensus communis merupakan suatu terobosan pada zamannya karena saat itu humaniora yang berbasis pada metodologi sangat mendominasi perkembangan humaniora. ${ }^{55}$

Tokoh berikutnya yang dirujuk oleh Gadamer adalah Anthony Ashley Cooper, the Third Earl of Shaftesbury (1671-1713), seorang filsuf dan politisi dari Inggris. Shaftersbury menulis esai berjudul Sensus Communis: An Essay on the Freedom of Wit and Humour. ${ }^{56}$ Dia memahami akal sehat sebagai perasaan tentang kebaikan bersama (common good). Shaftesbury melihat ada kesamaan antara common good dan koinonoemosune, istilah yang dipopulerkan oleh Marcus Aurelius (kaisar Romawi kuno). ${ }^{57}$

\footnotetext{
53 Gadamer, Truth and Method, hlm. 19.

${ }^{54}$ Gadamer, Truth and Method, hlm. 19.

${ }^{55}$ Gadamer, Truth and Method, hlm. 21

${ }^{56}$ Esai ini ditulis pada tahun 1709.

${ }^{57}$ Gadamer, Truth and Method, hlm. 22.
} 
Melalui sensus communis, Shaftesbury mengajak orang untuk mencintai komunitas dan masyarakat. Shaftesbury juga mengajak orang untuk saling membantu dan melaksanakan kewajiban masing-masing demi tercapainya kebaikan bersama. ${ }^{58}$ Shaftesbury menyatakan bahwa basis dari nilai kepedulian bukan hanya moralitas, melainkan juga pada metafisika estetika. Nantinya pandangan Shaftesbury ini dipakai oleh Francis Hutcheson dan David Hume yang kemudian akan dikembangkan dalam etika Kantian. ${ }^{59}$

Menurut Gadamer, pemikiran sensus communis dan akal sehat dari Shaftesbury mirip dengan konsep le bon sens yang dipopulerkan oleh Henri Bergson. Sebenarnya istilah le bon sens berarti perasaan, tetapi oleh Bergson, le bon sens dikaitkan dengan lingkungan sosial (milieu social) sehingga le bon sens berarti kepedulian seseorang terhadap komunitasnya. Bergson mengkritik ilmu pengetahuan modern yang mengabaikan dimensi sosial manusia. Bagi Bergson, le bon sens adalah suatu pengetahuan praktis yang berguna bagi hidup manusia dan menghindarkan manusia dari sikap dogmatis terhadap sesuatu, termasuk kemajuan ilmu pengetahuan modern. $^{60}$

Tokoh berikutnya adalah Friedrich Christoph Oetinger (1702-1782), seorang pendeta dan teolog Lutheran dari Jerman. Oetinger mengembangkan pandangan sensus communis dari Shaftesbury. Oetinger memaknai sensus communis sebagai "hati". Cara kerja hati tidak membutuhkan suatu konsep teoretis. Konsep teoretis bagi Ootinger tidaklah cukup sebagai pengetahuan tentang hidup. Ootinger mengambil contoh sikap orangtua terhadap anak-anaknya didasari oleh hati. ${ }^{61}$ Oetinger menyatakan bahwa perkembangan kehidupan dari yang sederhana berkembang

\footnotetext{
${ }^{58}$ Gadamer, Truth and Method, hlm. 22.

${ }^{59}$ Gadamer, Truth and Method, hlm. 22.

${ }^{60}$ Gadamer, Truth and Method, hlm. 23.

${ }^{61}$ Gadamer, Truth and Method, hlm. 24-25.
} 
menjadi kompleks bukan karena eksperimen dan kalkulasi, melainkan karena faktor jiwa manusia. Itulah inti dari konsep sensus communis. ${ }^{62}$

\subsection{Pertimbangan (Judgment)}

Unsur ketiga dari pemikiran humanisme adalah konsep pertimbangan (judgment). Gadamer melihat bahwa perkembangan konsep sensus communis di Jerman pada abad ke-18 berkaitan erat dengan perkembangan konsep pertimbangan. Istilah gesunder Menschenverstand (pemikiran yang sehat) sering kali juga disebut dengan Gemeiner Verstand (pemahaman umum), yang dalam kenyataannya ditentukan oleh adanya unsur pertimbangan. ${ }^{63}$ Karena kedua konsep itu mempunyai hubungan yang erat, dalam pembahasan mengenai pertimbangan, sering kali Gadamer mengaitkannya dengan pemikiran mengenai sensus communis.

Kata pertimbangan yang diperkenalkan pada abad ke-18 berasal dari kata judicium (judgment) yang dipandang sebagai suatu nilai intelektual dasar. Para filsuf moral abad ke-18 dari Inggris menekankan bahwa moral dan pertimbangan estetis tidak tunduk pada nalar. Pendapat senada muncul dari Johannes Nikolaus Tetens (17361807), seorang filsuf, psikolog, dan ahli matematika dari Jerman, yang memandang sensus communis sebagai suatu pertimbangan tanpa refleksi. ${ }^{64}$

Dari pandangan para filsuf moral di atas terlihat bahwa pertimbangan itu tidak bisa diajarkan atau dipelajari karena tidak ada penjelasan bagaimana seseorang mengambil suatu pertimbangan tertentu. Pertimbangan juga tidak bisa dipelajari secara abstrak. Pertimbangan harus diterapkan secara konkret dalam kehidupan sehari-hari. Mungkin karena itulah, para filsuf pencerahan dari Jerman menganggap konsep pertimbangan sebagai suatu kemampuan pemikiran yang rendah. ${ }^{65}$

\footnotetext{
62 Gadamer, Truth and Method, hlm. 25.

${ }^{63}$ Gadamer, Truth and Method, hlm. 27

${ }^{64}$ Gadamer, Truth and Method, hlm. 27.

${ }^{65}$ Gadamer, Truth and Method, hlm. 28.
} 
Vico dan Shaftesbury juga memberikan sumbangan yang penting bagi pengembangan konsep pertimbangan dalam kaitan dengan sensus communis. Bagi Vico dan Shaftesbury, sensus communis bukanlah suatu kemampuan intelektual yang digunakan oleh manusia, melainkan lebih pada upaya manusia untuk membuat sejumlah pertimbangan yang menentukan tindakan manusia.

Para filsuf moral abad ke-18 mempunyai pandangan yang menghormati keunikan atau sensivitas individual dari suatu pertimbangan. Mereka menolak meletakkan pertimbangan yang partikular di bawah yang universal. Salah satu tokoh yang mewakili pandangan semacam ini adalah Alexander Gottlieb Baumgarten (17141762), seorang filsuf Jerman. Menurut Baumgarten, konsep pertimbangan mengakui adanya sensivitas individual dan suatu tindakan yang unik. Pertimbangan seseorang tidak diperoleh dari suatu nilai yang universal tetapi lebih pada persetujuan seseorang atas hal-hal yang berbeda. ${ }^{66}$

Kant mempunyai pandangan yang berbeda dan berseberangan dengan para filsuf moral yang memberi tempat pada keunikan dan partikularitas dari suatu pertimbangan. Kant ingin menegakkan universalitas moral sehingga tidak ada tempat bagi sensus communis dalam filsafat moralnya. Kant mengajukan konsep apriori sebagai landasan filsafat moralnya. Kant tidak setuju jika moral didasarkan pada sensivitas individual atau pertimbangan partikular. Bagi Kant, setiap orang mempunyai unsur apriori dalam diri masing-masing dan unsur apriori itulah yang mendasari tindakan moral setiap orang sehingga filsafat moral bersifat universal. Dalam Methodology of Pure Practical Reason, Kant merumuskan langkah metodis dari moralitas manusia. Kant merumuskan sejumlah prinsip atau kategori sebagai pertimbangan manusia. Kategori moral itu bersifat imperatif dan menjadi tuntunan praktis bagi manusia dalam hidupnya.

\footnotetext{
${ }^{66}$ Gadamer, Truth and Method, hlm. 28.
} 
Gadamer mengkritik pemikiran Kant yang menolak dan meniadakan sensus communis sebagai bahan pertimbangan manusia. Kant menghilangkan individualitas manusia yang mempunyai perasaan moral tersendiri dan mempunyai kebebasan pertimbangan moral. Gadamer juga mengkritik upaya Kant menyusun pertimbangan moral dengan cara metodologis. Pada kenyataannya seseorang bisa membuat pertimbangan tanpa harus mengikuti langkah metodologi dari kategori-kategori moral yang disusun oleh Kant.

\subsection{Selera (Taste)}

"Mengetahui bagaimana cara memilih. Banyak hal dalam kehidupan bergantung pada pengetahuan kita untuk memilih. Anda butuh selera yang baik dan penilaian yang jujur. Inteligensia dan penerapan tidaklah mencukupi. Tidak ada yang sempurna tanpa sikap arif dan kemampuan menyeleksi. Dua hal terlibat: memilih dan memilih yang terbaik. Pengetahuan kita untuk memilih salah satu adalah anugerah terindah." 67 (Baltasar Gracian).

Konsep humanis keempat yang dikembangkan oleh Gadamer adalah taste (selera). Ketika membahas konsep selera, Gadamer merujuk pada pandangan Baltasar Gracian (1601-1658), seorang pastor Jesuit asal Spanyol, penulis prosa zaman Baroque, dan filsuf yang pemikirannya tentang selera berbeda dengan pandangan Kant tentang selera. Menurut Gadamer, konsep selera pada awalnya lebih berkaitan dengan aspek moral ketimbang estetika. Selera memberikan sikap kritis terhadap dogmatisme ilmu

\footnotetext{
67 "Know how to choose [buena elección]. Most things in life depend on it. You need good taste and an upright judgment [el buen gusto y el rectísimo dictamen]; intelligence [estudio] and application [ingenio] are not enough. There is no perfection without discernment and selection. Two talents are involved: choosing and choosing the best [poder escoger, y lo mejor]. [...] Knowing how to choose is one of heaven's greatest gifts [y así este es uno de los dones máximos de arriba]. Banyak hal di kehidupan bergantung pada pengetahuan kita untuk memilih. Anda butuh selera yang baik dan penilaian yang jujur. Inteligensia dan penerapan tidak mencukupi. Tidak ada yang sempurna tanpa sikap arif dan kemampuan menyeleksi. Dua hal terlibat: memilih dan memilih yang terbaik. Pengetahuan kita untuk memilih salah satu adalah anugerah terindah. Kutipan diambil Endre Szécsényi, "Gustus Spiritualis: Remarks on the Emergence of Modern Aesthetics" dalam Estetika: The Central European Journal of Aesthetics, Vol. LI/VII, No. 1, 2014, hlm. 62-85.
} 
pengetahuan (the school). Baru belakangan, selera lebih banyak digunakan atau terbatas dipakai di bidang estetika. ${ }^{68}$

Menurut Gracian, selera adalah sebuah titik awal dari pemisahan manusia dari kebinatangan yang ditandai dengan kemampuan manusia untuk membuat pilihan. Selera adalah "spiritualisasi dari kebinatangan" dalam arti manusia berkembang tidak hanya pada unsur pikiran, tetapi juga soal gusto atau selera. Gusto adalah pijakan dari kebudayaan sosial yang dikembangkan oleh Gracian. Manusia yang ideal, menurut Gracian, adalah manusia berbudaya yang memperoleh kebebasannya karena bisa melihat perbedaan dan mampu membuat pilihan-pilihan (Hombre en su punto). ${ }^{69}$

Terinspirasi oleh pemikiran Gracian, Gadamer mengembangkan konsep selera. Pertama, selera sebagai suatu moda pengetahuan. ${ }^{70}$ Selera adalah sebuah kemampuan intelektual yang dimiliki oleh manusia untuk membuat pilihan-pilihan dalam hidup. Melalui selera, seseorang dapat melakukan diferensiasi terhadap berbagai hal dalam hidup. Dengan melakukan diferensiasi, seseorang akan bisa memilih mana yang baik atau mana yang buruk.

Kedua, selera beroperasi dalam komunitas. Selera memang dimiliki oleh setiap orang, tetapi bukan berarti bahwa selera itu hanya bersifat individual. Menurut Gadamer, selera merupakan fenomena sosial. Seseorang bisa menyukai sesuatu meskipun sebenarnya itu bertentangan dengan selera pribadi. Dalam kehidupan sosial, menurut Gadamer, berlaku de gustibus non est disputandum, yaitu selera seseorang bisa berbeda dengan selera orang lain, tetapi perbedaan selera jangan menjadikan sebab perselisihan antar-orang di dalam suatu komunitas. ${ }^{71}$

\footnotetext{
${ }^{68}$ Gadamer, Truth and Method, hlm. 31.

${ }^{69}$ Gadamer, Truth and Method, hlm. 31.

${ }^{70}$ Gadamer, Truth and Method, hlm. 32.

${ }^{71}$ Dalam hal ini Gadamer menyetujui pandangan Kant yang menyatakan bahwa perbedaan selera tidaklah dijadikan bahan perselisihan. Lihat Gadamer, Truth and Method, hlm. 32
} 
Ketiga, Gadamer menyatakan bahwa selera lebih berkaitan dengan soal rasa dibandingkan dengan rasio. Dalam realitas, seseorang bisa saja tidak punya alasan tertentu untuk menyukai dan memilih sesuatu, tetapi orang tersebut meyakini dengan pasti terhadap selera yang dipilihnya. ${ }^{72}$

Keempat, selera mempunyai unsur kebebasan. Dengan menyatakan selera sebagai fenomena sosial, bukan berarti selera individu harus tunduk sepenuhnya kepada selera komunitas. Menurut Gadamer, dalam selera ada unsur kebebasan. Seorang individu bisa mempertahankan kebebasannya untuk setuju atau tidak setuju dengan selera komunitas. Selera seseorang tidak bergantung atau tidak tunduk kepada aturanaturan yang berlaku di komunitasnya. ${ }^{73}$

Pandangan soal selera dari Gracian ternyata tidak lama berkembang karena muncul pandangan Kant yang sangat berbeda tentang selera. Dalam penelitiannya tentang dasar-dasar selera, Kant menemukan suatu fakta bahwa ada unsur apriori dalam diri manusia. Unsur apriori itu bersifat universal, tetapi berbeda dari universalitas yang empiris dari selera sebagaimana diyakini oleh para pemikir sebelumnya. ${ }^{74}$ Selera tidak bergantung pada selera individu yang satu dengan selera individu yang lain. Selera muncul karena ada perasaan senang dalam diri semua manusia.

Menurut Gadamer, pengaruh pemikiran Kant begitu dominan terhadap perkembangan ilmu-ilmu sosial. Fenomena tersebut telah mengabaikan sumbangan penting dari pemikiran Gracian soal selera. Kant telah mengabaikan relasi yang dinamis antara individu dan komunitas seperti yang dipertahankan dalam pemikiran tentang selera dari Gracian. Kant berupaya meletakkan selera sebagai bagian dari penggunaan akal budi teoretis dan akal budi praktis.

\footnotetext{
${ }^{72}$ Gadamer, Truth and Method, hlm. 32-33.

${ }^{73}$ Gadamer, Truth and Method, hlm. 33.

${ }^{74}$ Gadamer, Truth and Method, hlm. 37.
} 
Menurut Gadamer, ada paradoks ketika para pendukung keunikan metodologi humaniora mendasarkan pada pemikiran Kant. Kant berupaya untuk membuat suatu pandangan moralistis yang transenden dan universal yang mengatasi partikularitas dan tradisi yang khas dari perkembangan konsep selera. Ketika pemikiran Kant digunakan, penekanan pada metode yang unik dari humaniora, di mata Gadamer, menjadi kehilangan pembenarannya. ${ }^{75}$

\title{
V. Penutup
}

\begin{abstract}
Metodologi adalah diskursus paling panas dalam pengembangan ilmu pengetahuan, dari abad ke-18 sampai zaman Gadamer mulai berkarya. Gadamer juga membahas pengaruh metodologi di bagian awal TM. Metode mulai diperkenalkan oleh Descartes sebagai hasil meditasi Descartes dalam menghasilkan fondasi pengetahuan yang tidak tergoyahkan. Menurut Gadamer, metodologi mendapat momentumnya sejak Kant menuliskan karyanya di bidang filsafat moral.
\end{abstract}

Momentum berikutnya bagi dominasi metodologi adalah kebutuhan universitas, khususnya di Jerman, untuk membuka fakultas-fakultas ilmu pengetahuan yang baru dan semakin kompleks. Metodologi menjadi suatu basis pengembangan ilmu pengetahuan di universitas-universitas di Jerman.

Gadamer mengambil sikap kritis terhadap pengaruh dan dominasi metodologi dalam pengembangan ilmu pengetahuan. Gadamer juga mengkritik klaim kebenaran yang diusung oleh para pembela metodologi sebagai satu-satunya upaya mencapai kebenaran. Gadamer melihat bahwa diskursus metodologi telah mengabaikan dan meminggirkan humanisme yang sebenarnya telah memberikan sumbangan yang sangat penting bagi pengembangan ilmu pengetahuan dan dalam tindakan manusia sehari-hari. Gadamer kemudian menghidupkan kembali diskursus humanisme sebagai suatu sumber

\footnotetext{
${ }^{75}$ Gadamer, Truth and Method, hlm. 36.
} 
pengetahuan. Berangkat dari refleksi kritis terhadap diskursus metodologi dan upaya menghidupkan kembali tradisi humanisme, Gadamer menyusun pemikirannya mengenai pengembangan pengetahuan manusia sekaligus menawarkan cara berpikir dan berfilsafat yang baru.

\section{Daftar Pustaka}

\section{- Buku:}

Gadamer, Hans-Georg. Truth and Method, Second Revised Edition, Translation revised by Joel Weinsheimer and Donald G. Mar, London: Continuum Publishing Group, 2004.

Grondin, Jean. Introduction to Philosophical Hermeneutic, translated by Joel Weinsheimer. New Haven: Yale University Press. 1994.

Gusmao, Martinho G. da Silva. Hans-Georg Gadamer: Penggagas Filsafat Hermeneutik Modern yang Mengagungkan Tradisi. Yogyakarta: Kanisius. 2013.

Palmer, Richard E. Hermeneutics: Intepretation Theory in Schleiermacher, Dilthey, Heidegger, and Gadamer. Illinois: Northwestern University Press. 1969.

Patton, Lydia, "Methodology of the Sciences" dalam Michael Forster and Kristin Gjesdal (ed). The Oxford Handbook of German Philosophy in the Nineteenth Century. Oxford: Oxford University Press, 2015.

Ritzer, George. Sociological Theory. New York: McGraw Hill. 2009.

Silverman, Hugh J (ed). Continental Philosophy IV: Gadamer and Hermeneutics. New York: Routledge, 1991.

Sullivan, Robert R. Political Hermeneutics: The Early Thinking of Hans-Georg Gadamer. Pennsylvania: The Pennsylvania State University Press.1989.

Turner, Jonathan H. "The Origins of Positivism: The Contributions of Auguste Comte and Herbert Spencer" dalam George Ritzer and Barry Smart (eds). Handbook of Social Theory. London: Sage Publication. 2001.

\section{- Artikel:}


Bakker, J.I. (Hans). "Wilhelm Dilthey: Classical Sociological Theorist" dalam Quarterly Journal of Ideology, 10 Mei 1998.

Kim, Kyung-Man. “Max Weber's Axiological Critique of the Methodology of the Human Sciences: The Methodenstreit and Ideal Types” dalam Korean Journal of Sociology Vol. 42. No. 4. Juni 2008.

Kinzel, Katherina. "Method and Meaning: Ranke and Droysen on the Historian's Disciplinary Ethos" dalam History and Theory Vol. 59, No. 1, Maret 2020.

Szécsényi, Endre. "Gustus Spiritualis: Remarks on the Emergence of Modern Aesthetics” dalam Estetika: The Central European Journal of Aesthetics Vol. LI/VII. No. 1. 2014. 